\title{
Preparation and Characterization of NiMo/C Using Rapid Heating and Cooling Method for Renewable Diesel Synthesis from Nyamplung Oil (Calophyllum Inophyllum Oil)
}

\author{
Bambang Heru Susanto ${ }^{1, *}$, Muhammad Bagus Prakasa ${ }^{1}$, Muhammad Husein Shahab ${ }^{1}$
}

\begin{abstract}
The synthesis of metal nanocrystal was conducted by modification preparation from simple heating method which heating and cooling process run rapidly. By used $\mathrm{NiMo} / \mathrm{C} 700{ }^{\circ} \mathrm{C}$ catalyst for 30 minutes which had surface area of $263.21 \mathrm{~m}^{2} / \mathrm{gram}$, had $31.77 \mathrm{~nm}$ crystal size, and good morphology of material, obtained catalyst with high activity, selectivity, and stability. After catalyst activated, synthesis of renewable diesel performed in hydrodeoxygenation reactor at $375{ }^{\circ} \mathrm{C}, 12 \mathrm{bar}$, and $800 \mathrm{rpm}$ for residence time of 150 minutes. The result of conversion was $81.99 \%$, yield was $68.08 \%$, selectivity was $84.54 \%$, and spesification met the petroleum diesel standard.
\end{abstract}

Keywords - Hydrodeoxygenation, NiMo/C, Nyamplung Oil, Rapid Heating and Cooling, Renewable Diesel.

\section{INTRODUCTION}

B iofuels has a good potential to fulfill energy needs in Indonesia as well as in the world. Biofuels are able to be alternative energy when the production of petroleum energy are depleted over time. Biodiesel is one of the biofuels which can be produced from trans esterification of triglyceride by using renewable resources. Unfortunately, biodiesel gave low oxidative stability, higher viscosity, higher cloud point and pour point, higher nitrogen oxides $\left(\mathrm{NO}_{\mathrm{x}}\right)$ emissions, lower energy density, and higher injector/engine wear [1]. To avoid the disadvantageous physical properties of oxygenated fuels, hyrodeoxygenation of non-edible vegetable oil has been investigated as an alternative pathway of biofuel production. Among the vegetable oils, nyamplung oil is known to be one of the most potential alternatives because of its high amount of seed production and high oleic acid content.

Hydrodeoxygenation belongs to a group of hydrotreating reactions and it means removal of oxygen from an oxygencontaining compound under hydrogen pressure at high temperatures with helped by heterogenous catalyst, which product known as renewable diesel [2]. The hydrodeoxygenation process consisted of decarboxylation, decarbonylation, and hydrogenation reaction as can be seen below.

Decarboxylation :

$$
\mathrm{C}_{17} \mathrm{H}_{35} \mathrm{COOH} \rightarrow \mathrm{C}_{17} \mathrm{H}_{36}+\mathrm{CO}_{2}
$$

Decarbonylation :

$$
\mathrm{C}_{17} \mathrm{H}_{35} \mathrm{COOH}+\mathrm{H}_{2} \rightarrow \mathrm{C}_{17} \mathrm{H}_{36}+\mathrm{H}_{2} \mathrm{O}+\mathrm{CO}
$$

Hydrogenation :

$$
\mathrm{C}_{17} \mathrm{H}_{35} \mathrm{COOH}+3 \mathrm{H}_{2} \rightarrow \mathrm{C}_{18} \mathrm{H}_{38}+2 \mathrm{H}_{2} \mathrm{O}
$$

$\mathrm{H}_{2}$ gas can convert fatty acids directly to hydrocarbons and water with losing any carbon atom. Metal in catalyst and pressured hydrogen is useful for saturation process of unsaturated carbon chains in triglycerides. Hydrodeoxygenation can be very expensive process due to the temperature and pressure requirements to deoxygenate of $300-400{ }^{\circ} \mathrm{C}$ with hydrogen pressure up to 200 bar. However, aromatic structures can be preserved which yields a high octane fuel [3].

Catalyst which has highly porous and thermostable material is able not only to disperse the metal, but also to increase its thermal stability and hence the catalyst life such as nickel molybdenum as active site. The active phase of the catalyst $\mathrm{Ni}$ and Mo itself does not have a large surface so that the reaction would be ineffective and inefficient due to not all of the active site can make contact with the reactants. Therefore, Ni and Mo metal component needs to be distributed on a surface of a solid support which has large surface area such as activated carbon. NiMo catalyst also can reduce the coke formation rate [4]. Mo is found to facilitate the reduction, and promoting $\mathrm{C}-\mathrm{O}$ activation while inhibiting the $\mathrm{C}-\mathrm{C}$ breaking.

This NiMo/C catalyst synthesized through modification of simple heating method which heating and cooling process run rapidly [5]. Several studies using simple heating method are: Liherlinah et al. [6] synthesizing $\mathrm{CuO} / \mathrm{ZnO} /$ Alumina catalysts to fuel cell applications for 30 minutes; Vioktalamo, A.S. [7] synthesize $\mathrm{Y}_{2} \mathrm{O}_{3} / \mathrm{Gd}$ catalysts to decompose of pollutant for 30 minutes with holding time of 30 minutes, and Fransisca [8] synthesizing $\mathrm{NiMo} / \mathrm{C}$ catalysts for renewable diesel production. Studies above were using the same method but with different treatments.

Hydrodeoxygenation reaction of nyamplung oil using hydrogenation reactor with a $\mathrm{NiMo} / \mathrm{C}$ catalyst at temperature $375^{\circ} \mathrm{C}$ and a hydrogen pressure 12 bar [9]. A high enough temperature is important to increase the cracking activity. However at temperature higher than $380{ }^{\circ} \mathrm{C}$, cracking of the hydrocarbons increases and hence the yield of diesel become decreases. The products were characterized by FT-IR (Shimadzu) and GC-MS (Agilent) to find functional groups and components of renewable diesel. The aim of this experiment is to investigate the effect of temperature and calcination time during the catalyst preparation step on the activity, stability, selectivity, conversion, and yield of triglyceride content in nyamplung oil to renewable diesel product. 


\section{MEthodology}

\section{A. Materials}

This study was conducted in two steps namely the preparation and characterization of nanocrystal $\mathrm{NiMo} / \mathrm{C}$ catalyst and synthesis of renewable diesel in a hydrogenation reactor. The following chemicals were commercially available and used as received: Nyamplung Oil (UNS Semarang) as raw material, Activated carbon (Merck) as catalyst support, $\left(\mathrm{NH}_{4}\right)_{6} \mathrm{Mo}_{7} \mathrm{O}_{24} \cdot 4 \mathrm{H}_{2} \mathrm{O}$ and $\mathrm{Ni}\left(\mathrm{NO}_{3}\right)_{2} \cdot 6 \mathrm{H}_{2} \mathrm{O}$ (Merck) as the source of the active nucleus, Polyethylene Glycol or PEG (Merck) as continuous media, Demineralized Water (Bratachem Indonesia) and Aquadest (CV. Dwinika) as a solvent.

\section{B. Catalyst Preparation}

Nanocrystal of nickel molybdenum on carbon support was prepared by rapid heating and cooling method adopted from Liherlinah [6] and Vioktalamo [7]. These catalysts were assigned as $5 \mathrm{wt} \% \mathrm{NiMo} / \mathrm{C}$ [9] and required amounts of the precursor salts and polyethylene glycol, i.e., $\left(\mathrm{NH}_{4}\right)_{6} \mathrm{Mo}_{7} \mathrm{O}_{24} .4 \mathrm{H}_{2} \mathrm{O}$, and $\mathrm{Ni}\left(\mathrm{NO}_{3}\right)_{2} \cdot 6 \mathrm{H}_{2} \mathrm{O}$ were dissolved in demineralized water. Then, activated carbon was addded dropwise with constant stirring followed by heating at $100{ }^{\circ} \mathrm{C}$ for 40 minutes in that solutions to evaporize water. Polymer solution, as continous media, was used to avoid agglomeration of particle group of catalyst. Therefore the polymer should be remained until the end of the process. Finally the mixture was heated in furnace to evaporize the PEG polymer and to produce the final nanocrystal NiMo/C catalyst at $575{ }^{\circ} \mathrm{C}, 600{ }^{\circ} \mathrm{C}$, and $700{ }^{\circ} \mathrm{C}$ for 30 minutes and 60 minutes with holding time 30 minutes. After that, NiMo/C catalysts were rapidly cooled (quenching process) with ice blocks. The catalysts were removed and stored in bottle of sample.

\section{Catalyst Characterization}

The catalysts were characterized by XRD (Shimidzu) to determine crystal size and type of crystal catalyst, BET (Micromeritrics ASAP 2020) to determine surface area, pore size and pore volume of catalyst and SEM-EDAX (JED-2300 Analysis Station JEOL) to determine the morphology and composition of the catalyst.

\section{Catalyst Activation Test}

Catalyst activation was carried out at $400{ }^{\circ} \mathrm{C}$ with internal temperature being measured by thermocouple. Before catalyst activation, the reactor was purged with nitrogen during experiment (30 minutes) to remove any oxygen content that might have been dissolved and present in nyamplung oil so that activity of catalyst will increase. After that, added hydrogen gas of 10 bar and the temperature was slowly decreased into $100{ }^{\circ} \mathrm{C}$ to provide activition performace during the reaction.

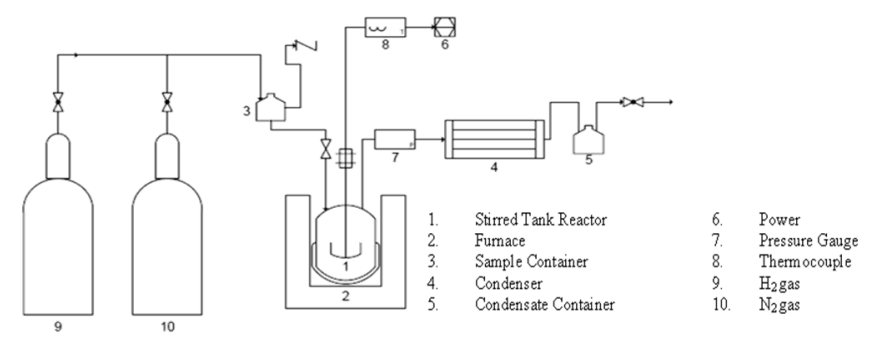

Fig. 1. Scheme of Hydrodeoxygenation Reactor

\section{E. Hydrodeoxygenation of Nyamplung Oil}

The reaction was carried out in a $330 \mathrm{~mL}$ semi batch stirred reactor integrated with a condenser and furnace. Extensive stirring of the oil and catalyst in the reactor was achieved using a magnetically driven stirrer with a DC geared motor. Nyamplung oil was used as feed and $\mathrm{NiMo} / \mathrm{C}$ as a catalyst with a feed ratio of 100:1 wt. Nitrogen gas was purged for 30 minutes. Stirrer speed and pressure during the reaction was kept constant at $800 \mathrm{rpm}$ and 12 bar respectively. The reaction was performed at temperature 375 ${ }^{\circ} \mathrm{C}$ for 2.5 hours. When the inside temperature of the reactor reached the target value, the hydrogen pressure was adjusted to the desired value. From this time onwards, the reaction time was occured. In this step, the double bonds that were present in the tryglycerides were saturated with hydrogen gas. Every 15 minutes, the resulting gas was analyzed online by GC-TCD to identify the hydrogen, carbon dioxide, carbon monoxide and methane gas. The gas products were condensed and collected as condensate. Fig. 1 above shows a schematic diagram of the apparatus. The bottom product was distillated using Koehler Model K 45090 according to the boiling range of petroleum products in three categories i.e. IBP-200 ${ }^{\circ} \mathrm{C}$, 200-300 ${ }^{\circ} \mathrm{C}$, and 300-EP. Distillation products at temperature 300-EP were carried out to determine the physical and chemical properties of renewable diesel product.

\section{RESULTS AND DisCUSSION}

\section{A. Result of Catalyst Characterizations}

\section{1) BET Characterization}

From BET characterization result, the surface area of catalysts will increase with increasing of temperature. The best catalyst that gives highest surface area is $\mathrm{NiMo} / \mathrm{C}$ with temperature $700{ }^{\circ} \mathrm{C}$ for 30 minutes. This catalyst has surface area $263.21 \mathrm{~m}^{2} /$ gram. Large surface area of the catalyst was needed to increase the collision between particles so it would increase the rate of reaction as well as the kinetics reaction [6]. This NiMo/C $700{ }^{\circ} \mathrm{C}$ catalyst was continued confirmed through several tests by SEM-EDAX and XRD to see

Table 1. Result of BET Characterization

\begin{tabular}{llll}
\hline \hline Sample & $\begin{array}{l}\text { Surface Area } \\
\left(\mathbf{m}^{2} / \text { gram }\right)\end{array}$ & $\begin{array}{l}\text { Pore } \\
\text { Volume } \\
\text { (cc/gram) }\end{array}$ & $\begin{array}{l}\text { Pore Size } \\
(\mathbf{n m})\end{array}$ \\
\hline NiMo/C-1 & 226,26 & 0,13 & 2,25 \\
NiMo/C-2 & 252,38 & 0,13 & 2,11 \\
NiMo/C-4 & 184,45 & 0,11 & 2,17 \\
NiMo/C-3 & 263,21 & 0,15 & 2,23 \\
\hline \hline
\end{tabular}


morphology and crystal size of catalyst. Increasing temperature led to more rapid PEG vaporization and sintering of catalyst which occured during reaction but due to activated carbon stable with high temperature, so that increasing of temperature can not effect of catalyst surface area.

$\mathrm{NiMo} / \mathrm{C} 700{ }^{\circ} \mathrm{C}$ also gives largest pore volume which indicating that the carbon structure has a large enough pore spaces. In catalysis reaction, large volume is needed to achieve the complete reaction, as the site of the reaction medium and can be regarded as a mini reactor [10]. The reason for low surface area and pore volume for this catalyst could be attributed to the pore blocking by NiMo metal. For sample of NiMo/C that was not kept constant, had higher surface area and the sintering that occured on the catalyst to be weaker than other temperature profile.

\section{2) XRD Characterization}

The result of XRD characterization can be seen on Fig. 2 above. Carbon which originally had a weak peak, after impregnated the catalyst on the surface has a sharp peak. The intensity of the peak represents the crystallinity. The sharper peak obtained, means particles tend to be better crystallinity. High crystallinity also will affect to the catalytic activity and stability at high temperatures. High crystallinity can also be regarded that the impregnation process is free from the impurities so that the physical properties of the catalyst $\mathrm{NiMo} / \mathrm{C}$ is not compromised.

Diffractogram also shows that size of Carbon, NiMo4, and $\mathrm{MoO}_{3}$ crystal supported on activated carbon estimated from the Scherrer formula are $45.52 \mathrm{~nm}, 29.55 \mathrm{~nm}$ and $20.24 \mathrm{~nm}$. From this result, the crystals size which formed were nanocrystalline.

\section{3) SEM-EDAX Characterization}

Morphology plays an important role in activity and selectivity of the catalyst. From Fig. 3 below, it can be seen that the magnification of $1000 \mathrm{x}$ and $10000 \mathrm{x}$, the $\mathrm{NiMo} / \mathrm{C}$ catalyst have the morphology which tend to be agglomerate and consist of small particles and large particles. Even though the interaction between molybdenum oxide and activated carbon is weak, the high surface area of activated carbon still allows for a high dispersion and a complete sulfidation of the oxide species.

Based on EDAX characterization result, the average yield active core NiMo content in the catalyst was $6.76 \mathrm{wt} \%$. This number is almost close to the number of active nuclei was added during preparation which is $5 \mathrm{wt} \%$. Increasing metal loading favors sintering due to weak interaction with



Fig. 2. Diffractogram of NiMo/C Catalyst


Fig. 3. Catalyst Morphology of NiMo/C Catalyst at (a) 1000x (b) 10000x Magnification

supported phase, agglomeration and micropore blocking could also take place [4].

\section{B. Renewable Diesel Characterizations}

Reactions of hydrodeoxygenation were carried out after the catalyst activation completed and the reactor temperature reaches $100{ }^{\circ} \mathrm{C}$. Hydrodeoxygenation of nyamplung oil was performed with two sample catalysts which had lowest crystal size, highest surface area, and good morphology namely $\mathrm{NiMo} / \mathrm{C}$ and $\mathrm{NiMo} / \mathrm{C}$ activated. After HDO reaction, the products still in mixture and had to be purified through distillation process. Distillation products at temperature 300EP were carried out to determine the physical and chemical properties of renewable diesel product.

Based on Table 2 below, density of nyamplung oil decreased due to nyamplung oil converted into Renewable Diesel. It shows that the cracking and hydrodeoxygenation reaction over both of $\mathrm{NiMo} / \mathrm{C}$ catalysts occurred. In Table 2, it also can be seen that the viscosity of nyamplung oil decreased after hydrodeoxygenation until $98 \%$ into Renewable Diesel. It was caused by the carboxylate bonding termination of nyamplung oil which containing a carbonyl group (CO) and hydroxyl (-OH). Hydroxyl group in the carboxylic bond can form hydrogen bonds with the carbonyl group (CO) which lead to stronger bonds between the molecules and the higher viscosity [11]. Low viscosity is good for injection system of diesel machine, and will not destroy the homogenity of fuel and air in combustion chamber [12]. In addition, the viscosity values generated by the renewable diesel product is much better comparing with the standard viscosity of biodiesel based on standard EN 14214 with a minimum viscosity 3.5 cst. Beside that, cetane index value is determined to find out the quality of combustion, emissions and the ability of the fuel to combust at the low temperature. Table 2 shows that the cetane index values of renewable diesel products meet the minimum cetane index of diesel fuel (ASTM D975). 
GCMS shows that the distillation bottom products consist of hydrocarbon fractions $\left(\mathrm{C}_{5}-\mathrm{C}_{23}\right)$ and oxygenates such as acetone, alcohol, aldehyde, carboxylic acid, etc. The percentage of oxygenate contained in the products less than $15 \%$ as can be seen on Table 4 below.

$\mathrm{NiMo} / \mathrm{C}$ activated was a sample that produced the largest mass percentage of renewable diesel fraction $(84.54 \%)$ and smallest percentage of oxygenate $(10.29 \%)$. Based on this result, it can be seen that $\mathrm{NiMo} / \mathrm{C}$ activated catalyst was the suitable catalyst to produce renewable diesel with the largest hydrocarbon content.

From Table 3-4 it can also be seen that the largest conversion of reactants occurred at $\mathrm{NiMo} / \mathrm{C}$ activated catalyst with $81.99 \%$. Similar with conversion, $\mathrm{NiMo} / \mathrm{C}$ activated also has the largest selectivity and yield of $\mathrm{C}_{12}-\mathrm{C}_{18}$ fraction (diesel fraction) which are $84.54 \%$ and $68.08 \%$. Based on this data, $\mathrm{NiMo} / \mathrm{C}$ activated catalyst is proved have a high activity and able to transform nyamplung oil into renewable diesel.

To evaluate the effectiveness and selectivities of $\mathrm{NiMo} / \mathrm{C}$ activated catalyst in desrided hydrodeoxygenation pathway, so analysis of gas products with GC-TCD were important as seen at Fig. 4 below. From Fig. 4., NiMo/C activated catalyst was selective to decarboxylation reaction as Eq. 1 above. This reaction can break oxygen bond so that alkane bond can be produced which indicates $\mathrm{CO}_{2}$ gas was high, approximately $80 \%$. This $\mathrm{NiMo} / \mathrm{C}$ activated catalyst also can minimize rhe production of methane and $\mathrm{CO}$ gasses, so that alkene bond which undesirable product was not formed. In Fig. 4 also ilustrates that there is no significant reduction in the formation of $\mathrm{CO}$ and $\mathrm{CO}_{2}$ gasses. This decrease indicates that the possible reduction of these gasses have been caused by fewer reactants can react and also due to the deactivation of the catalyst. Deactivation of the catalyst is probaby due to the collapse of activated carbon's structure. Therefore, can be conclued that $\mathrm{NiMo} / \mathrm{C}$ activated catalyst which has highest loading, highest surface area, and lowest crystal size, can convert nyamplung oil to renewable diesel with yield was $68.08 \%$, conversion was $81.99 \%$, and selectivity was $84.54 \%$.

Table 2. Comparison Physical Properties of Renewable Diesel with Other Products

\begin{tabular}{cccc}
\hline \hline Sample & $\begin{array}{c}\text { Density-ASTM } \\
\text { D86 [gram/mL] }\end{array}$ & $\begin{array}{c}\text { Viscosity- } \\
\text { ASTM D7042- } \\
\text { 04 [cst] }\end{array}$ & $\begin{array}{c}\text { Cetane Index- } \\
\text { ASTM D975 }\end{array}$ \\
\hline NiMo/C & 0.86 & 1.37 & 54 \\
NiMo/C & 0.78 & 1.16 & 81.83 \\
activated & & & \\
Nyamplung Oil & 0.94 & 90.88 & - \\
Biodiesel & 0.85 & 2.30 & 51 \\
Diesel & 0.82 & 1.90 & 40 \\
SNI & $0.85-0.89$ & $2 \mathrm{~s} / \mathrm{d} 6$ & Min. 51 \\
\hline \hline
\end{tabular}

Table 3. Selectivity and Yield of Distillation Product (300-EP)

\begin{tabular}{llll}
\hline \hline Sample & Product & \% Selectivity & \% Yield \\
\hline \multirow{3}{*}{ NiMo/C activated } & Biogasoline & 12.32 & 9.92 \\
& Biokerosene & 2.35 & 1.89 \\
& Renewable diesel & 84.54 & 68.08 \\
& Lubricant & 0.79 & 0.64 \\
\hline \hline
\end{tabular}

Table 4. Conversion and Hydrocarbon, Oxygenate, and Aromatic Components of Products

\begin{tabular}{lll}
\hline \hline & NiMo/C activated & NiMo/C \\
\hline$\%$ Conversion & 81.99 & 81.05 \\
$\%$ Hydrocarbon & 89.71 & - \\
$\%$ Oxygenate & 10.29 & - \\
$\%$ Aromatic & 6.33 & - \\
\hline \hline
\end{tabular}

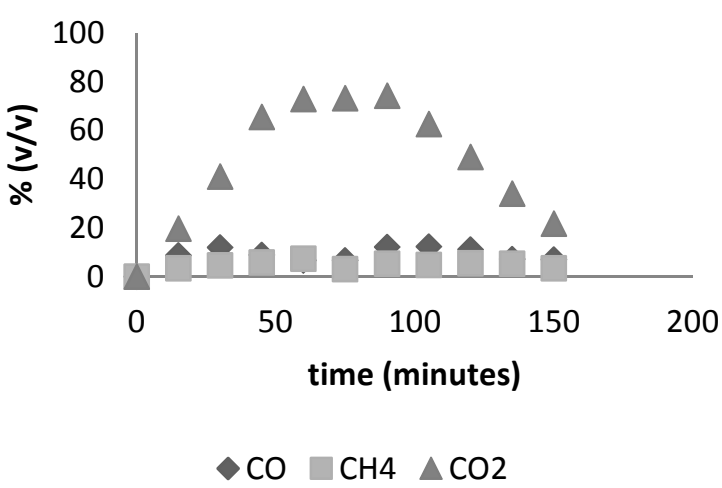

Fig. 4. Gas Products Result of NiMo/C Activated Catalyst

\section{CONCLUSION}

In this study, $\mathrm{NiMo} / \mathrm{C}$ catalysts were prepared by rapid heating and cooling method with polymer solution as a growth inhibitor. Characterization of catalysts have shown that the lowest crystal size of $31.77 \mathrm{~nm}$ and surface area of $263.21 \mathrm{~m}^{2} / \mathrm{g}$ which prepared at $700{ }^{\circ} \mathrm{C}$ when the heating temperature was not kept constant. The experimental conditions were $375{ }^{\circ} \mathrm{C}$ for average reaction temperature and 150 minutes for residence time. These condition with $\mathrm{NiMo} / \mathrm{C}$ activated led to dominant yield of $68.08 \%$ of diesel fraction $\left(\mathrm{C}_{13}-\mathrm{C}_{18}\right)$, conversion was $81.99 \%$, and selectivity was $84.54 \%$. It means the oxygenation removal pathway of nyamplung oil through $\mathrm{NiMo} / \mathrm{C}$ activated catalyst was successfully converted into the renewable diesel which the spesification met the petroleum diesel standard.

\section{REFERENCES}

[1] S. Lestari, Palvi M.A., Kari E., Beltramini J., Max L., Dmitry Y.M. "Diesel-like hydrocarbons from catalytic deoxygenation of stearic acid over support Pd nanoparticles on SBA-15 catalyst," Catalyst Letter, pp. 250-257, 2010.

[2] R. S. Boyás, Yanyong L., Tomoaki, M., "Production of renewable diesel by hydrocracking of canola oil on Ni-Mo/ $\gamma-\mathrm{Al}_{2} \mathrm{O}_{3}$ and Pt-zeolitic based catalysts," Instituto Politécnico Nacional, pp. 2-7, 2008.

[3] B. Veriansyah, Han, J. Y., "Production of renewable diesel by hydroprocessing of soybean oil: Effect of catalyst," Journal of Fuel, pp. 578-585, 2012

[4] M. Nasikin, Susanto, B.H., Katalis Heterogen, Universitas Indonesia Press: Indonesia, 2010, pp. 42-64.

[5] M. A. Abdullah, Khairunnijal, Maruly, A.R., Liherlinah, Sunny, M. "Sintesis dan pengujian katalis nanokristalin $\mathrm{Cu} / \mathrm{ZnO} / \mathrm{Al}_{2} \mathrm{O}_{3}$ dengan metode pemanasan dalam larutan polimer untuk aplikasi konversi metanol menjadi hidrogen," Jurnal Nanosains dan Nanoteknologi, vol. 1 No.1, pp. 1-25, 2008.

[6] M. A. Abdullah, Liherlinah, Khairurrijal, "Sintesis nanokatalis $\mathrm{Cu} / \mathrm{ZnO} / \mathrm{Al}_{2} \mathrm{O}_{3}$ dengan untuk mengubah metanol menjadi hidrogen," Jurnal Nanosains dan Nanoteknologi, pp. 2-7, 2009.

[7] A.S. Vioktalamo, "Synthesis $\mathrm{Y}_{2} \mathrm{O}_{3}$ : Gd nanoparticles using a polymer heating methods," Thesis, 2007. 
[8] G. Fransisca, "Sintesis renewable diesel dari minyak jarak melalui reaksi deoksigenisasi menggunaan katalis nano NiO/Alumina," Thesis, Departement of Chemical Engineering, Universitas Indonesia, Depok, 2012.

[9] A.C. Sinaga, "Preparasi, karakterisasi, dan uji reaksi katalis nano $\mathrm{NiO} / \mathrm{Al}_{2} \mathrm{O}_{3}$ untuk sintesis bahan bakar bio non ester dari minyak jarak melalui pirolisis berkatalis," Thesis, Departement of Chemical Engineering, Universitas Indonesia, Depok, 2011.
[10] A. Swiatkowski, Jankowska, J. Choma, Active Carbon, Ellis Horwood: New York, 1991, pp. 79.

[11] Z. Shichao, He Li., Shaohui Y., Ye L., Yanbiao R., "Pd/C catalyst synthesized by microwave assisted polyol method for methanol electrooxidation," International Journal of Electrochemical Science, pp. 29963009, 2013.

[12] H. Zhong, Yuan, "Hydrodeoxygenation of model compounds and catalytic system for pyrolysis bio-oils upgrading." Catalyst for Sustainable Industry, pp. 28-52, 2012. 